\title{
MIR92A2 Gene
}

National Cancer Institute

\section{Source}

National Cancer Institute. MIR92A2 Gene. NCI Thesaurus. Code C82047.

This gene is involved in the regulation of gene expression and plays an oncogenic role in hepatocellular carcinoma and medulloblastoma. 